\title{
Epistemological Understanding of Science Embedded within Shad Darsana and Buddhist Philosophy
}

\author{
Kamal Prasad Koirala, ${ }^{+*}$ Dr Bidya Nath Koirala ${ }^{i}$ and Dr Gem Prasad Gurung ${ }^{*}$
}

\section{Abstract}

This paper focuses on the epistemological understanding of finding the science embedded within Shad darsana and Buddhist philosophy. The primary rationale of this study is to dig out the scientific notion that consists of Shad darsana and Buddhist philosophy. Shad darsana or six systems of Hindu philosophy considered as the orthodox/astika philosophy and accept the authority of Vedas, which included Nyaya, Vaisesika, Sankey, Yoga, Poorva Mimamsa and Uttar Mimamsa. Pratyaksa/Perception, Anuman/Inference, Upamana/Comparison, Sabda (word) or testimony are considered the achieving and transforming ways of valid knowledge of Shad darsana like modern science. Astanga yoga, introduced by seer Patanjali, is regarded as a pioneer scientific practice in the modern era for the connection of mind, body and soul; and is useful to control the COVID 19 pandemic. Buddhist philosophy is considered as the heterodox/nastic or materialist philosophy; that is, it does not believe in the authenticity of Veda. It is mainly based on four universal truths and ways of elimination of sin doing practical meditation way. Madhyama Pratipada, Pratityasamutpada, Nirvana, Ksanabhangavada and Anatmavada are scientific processes of achieving knowledge in Buddhist philosophy.

Keywords: Shad Darsana; Cosmic Energy; Meditation; Materialistic Philosophy; Valid Knowledge

\footnotetext{
${ }^{\dagger}$ Lecturer of Science Education at the Gorkha Campus, Gorkha, Tribhuvan University, Nepal, and Ph.D. scholar of Faculty of Education, Graduate School of Education, Trivuvan University, Nepal

${ }^{*}$ Corresponding Author, Email: kamal.koirala@gc.tu.edu.np

ÎProfessor Bidya Nath Koirala, Senior Professor of Faculty of Education, Tribhuvan University Nepal, Email: sambedan@wlink.com.np

${ }^{*}$ Associate Professor, Sanothimi Campus Bhaktapur, Faculty of Education, Trivuvan University, Nepal, Email: gem_gurung@yahoo.com

(C) 2021 Koirala et al. This is an Open Access article distributed under the terms of the Creative Commons Attribution License (http://creativecommons.org/licenses/by/2.0), which permits unrestricted use, distribution, and reproduction in any medium, provided the original work is properly cited.
} 


\section{Introduction}

The six systems of philosophy called Shad darsana were developed in the sutra period as the last knowledge practice of Vedic philosophy. To find the Vedic truth, different Indian continental Vedic philosophers tried to search the truth through the multiplicity of the path, and Shad darsana has been pronounced by the thinkers to provide the systematic ways of Vedic knowledge. Sankar (2011), however, considered it orthodox Vedic knowledge because it is called astika philosophy and accepts directly or indirectly authority of the Veda and continuation of Vedic tradition. Radhakrishnan (1956 II) and Swami (2009) called it a system of thought or darsana or a Brahmanical system since they all accept the authority of Veda (p. 20). Therefore, the six systems of Veda are considered as six orthodox of Indian continental philosophy, although if the system of thought which admit the validity of Vedas or acknowledged the Veda as authoritative is called astika, and those which repudiate it to be nastika (Radhakrishnan, 1956 II, p. 20; Swami, n. d, p. 2). However, observing six systems of philosophy as the scientific epistemology, it is seen more nastika than that astika, and we have tried it to dig out scientific epistemic of knowledge construction consisted within Shard darsana. All branches of Indian continental philosophy deals with the "two subjects: pramanas, valid source of knowledge, and prameyas, things to be known through them" (Swami, 2009, p. 6).

There are many ways of learning and understanding science within astika (Shad darsana) and nastika philosophy (Buddhist philosophy) practiced as the eastern philosophy. Different religious and philosophical dimensions are practiced within Shad darsana and Buddhist philosophy; however, this study focuses on the epistemological way of understanding embedded science within Shad darsana and Buddhist philosophy. Many people understand that Shad darsana and Buddhist philosophy as the religious world view. In this study, we have tried here to dig out the epistemological practices of the scientific worldview embedded within them. We have attempted here to justify the Shad darsana and Buddhist philosophy as the scientific process of validation and falsification to claim them as scientific verification of knowledge. The epistemological practices of each are given below in a thematic way. In the following section, we discuss the epistemology and scientific practices of Nyaya and Vaisesika.

\section{Epistemology and Scientific Practices of Nyaya and Vaisesika}

The founder of Nyaya is Gautama. The Nyaya means arguments and suggests that the system is predominately intellectual, analytic, logical, and epistemological, and it focuses on Tarkashastra or the science of reasoning; Paramanashastra or science of logic and epistemology; Hetuvidhya, or the science of causes; Vadavidya or science of debate; and Aniviksiki or science of critical study (Sharma, 1991, p. 191). Like that the founder of Vaisesika is Kanada, and Vaisesika focuses on Padartha (world), mean object (experience) which can be thought (artha) and named (Pada), and the entire universe (physical as well as experience) is reduced to six or seven Padartha (Radhakrishna, 1956 II, p. 183; Sharma, 1991, p. 175-76). Vaisesika is used as the supplement to the Nyaya. So that both are called in combined form Nyaya-Vaisesika philosophy. Both Nyaya and Vaisesika are based on the modern scientific practices of logic and atomic theory (Pratt, 193334). According to Gotama and Kanada, there are pratyaksa/perception of valid knowledge, which mean intercourse of the sense organs (sense perception or direct apprehension) with the objects, means direct cognition without any instrumentality of any other cognition such as inference, comparison, and testimony (Muller, 1919, p. 374; Radhakrishnan, 1956 II, p. 48-49, Swami, n. d, p. 10). In pratyaksa, knowledge is not an antecedent condition; God knowledge is direct, immediate and entire, and not instrumented by any other condition (Radhakrishnan, 1956 II, p. 49). Ordinary perception presupposes the sense-organs, the object, the Manas (union of the soul with the 
mind) and self, and their mutual contact (Sharma, 1991). According to Radhakrishnan (1956 II), different factors involved in the act of perception: sense (indriyas), their objects (artha), the contact of sense with their object (sannikarsa), and cognition produced by this contact (Jnanam), inferences that there is used sense organs (p. 49). Manas (union of the soul with the mind) makes the sense organs to achieve specific qualities of an object such: smell, taste, colour, touch and sound and manifest them and mediate between the self and the sense-organs (Radhakrishnan, 1956 II; Sharma, 1991; Swami, n. d) and we perceive any things.

According to Gotama and Kanada, pratyaksa is further divided into laukika (ordinary), nirvikalpa (indeterminate) and alaukika (extraordinary), perceived by direct contacting sense object is called laukika, ordinary perception (Radhakrishnan, 1956 II; Sharma, 1991, Swami, 2009), whereas not direct obtained but conveyed to the senses through the unusual modes, then that perception is called alaukika (Swami, n. d, p. 11). Nyaya believes that when the ordinary internal perception comes in contact with external sense organs composed of the earth, water, fire, air, and ether, it can say that these sense organs are made by an atom of the earth (Sankar, 2011). Therefore, Yogis can perceive pratyaksa knowledge (Swami, 2009).

Anuman/Inference is the "process of knowing something not through contact between the senses and the objects of the world and not by observation but rather through the medium of a sign, or linga, that is invariably related to it" (Sharma, 1991, p. 197; Swami, n. d, p. 12). It is considered a more scientific way to the knowledge validation process, and cognition presupposes some other cognition. It consists of three-term which are interlinked (Muller, 1919) with each other; for example, when we know that smoke is invariably associated with fire (vyapti) and if we see smoke in a hill, we conclude that there must be the fire in that hill (Gupta, 1980; Swami, 2009). Hill is the minor term; fire is the major term; smoke is the middle term (Gupta, 1980, p. 135; Swami, n. d, p. 12). It is seen as scientific because it uses the five members of the syllogism, which are: proposition or pratijna (the hill is on fire), reason or hetu (because of smoke on fire), udaharana or explanatory example (fire shows smoke), upanaya or application (smoke is related with fire), and nigaman or conclusion (therefore this hill has fire) (Radhakrishnan, 1956 II, p. 75; Swami, n. d, p. 13). These arguments also indicate an embedded scientific procedure within the Nyaya Vaiseshika philosophy like the Aristotelian logic.

Both induction and generalisation (deduction) methods are applied in Nyaya and Vaisesika for the validation knowledge as scientific methods use it; however, here, the conclusion is not logical inference; it is warranted by the premises, while Indian continental syllogism is somehow different from Greek logic because it is based on empirical reason and acceptance the western science and mathematics only (Radhakrishnan, 1956 II, Swami, 2009); actually, the Nyaya and Vaisesika methods of inference used inductive reasoning; in which conclusion is drawn on the grounds of a broad and universally known truth (Swami, n. d, p. 14). The inference is conducted neither with regards to things unknown nor known definitely for certain, it functions only doubtful conditions. Moreover, perception relates to object which perceive the present, while inference relates to the present, past, and future (Swami, n. d). Nyaya considered that no cause could exist without producing the effect; both are in an inseparable union, they are not separate, only two modes of one thing.

Upamana/comparison is considered the third valid experimental knowledge source in Nyaya Vaisesika philosophy (Swami, n. d). Radhakrishnan (1956 II) argues that Upamana or Comparison is the "means by which we gain the knowledge of a thing from its similarity to another thing previously well known" (p. 102). Upamana is knowledge derived from comparison and roughly corresponds to the analogy, knowledge of the relation between words and their denotation. It produces knowledge of resemblance or similarity (Sankar, 
2011). About the comparison Sankar (2011) gave an example, which is as follows

a man who has never seen a gavaya or a wild cow and does not know what it is, is told by a person that wild cow is an animal like a cow, subsequently comes across a wild cow in a forest and recognises it as the wild cow, then his knowledge is due to upamana. He has heard the word 'gavaya' and has been told that it is like a cow and now he himself sees the object denoted by the word 'gavaya' and recognises it to be so. (p. 30)

Between a name and the object denoted by that name. When one perceives the similarity to the cow, remember that gavaya is an animal like a cow (Sharma, 1991, p. 203; Swami, 2009, p. 13). This comparison is seen in the present, like the ancient sages used for their medicine verification. For example, if a theory of medicine propounded by the sages of old is tested and found true, then the science of spiritual freedom as expounded by them also must be true (Radhakrishnan, 1956 II, p. 104).

Another valid source of knowledge in the Nyaya and Vaisesika systems is sabda (word) or the testimony of verbal knowledge. It is called the fourth and final source of valid experimental knowledge (Swami, n. d). The logical issues involved in the mode of acquiring knowledge are discussed under sabda or verbal knowledge (Radhakrishnan, 1956 II, p. 104). A trustworthy person understands the meaning of sabda (Swami, 2009). According to ancient Nyaya, the power in a word to convey its meaning comes from God, and according to later Nyaya, from the long-established convention (Sharma, 1991, p. 204). Testimony is always personal. It is based on the words of a trustworthy person, human or divine (Swami, n. d). Testimony is two types of Vaidika and secular. Vaidika testimony is perfect and infallible, such as Veda is spoken by God (Sharma, 1991; Radhakrishnan II, 1956); secular words are spoken by a human being liable to truth or errors; only the word trustworthy person who always tells the truth is valid, others not (Muller, 1919; Swami, n. d). The word is a powerful symbol that denotes an object, and a sentence is a collection of words, and these sentences would be intelligent and offer four conditions: Akanksa, Yogyata, Sannidhi and Tatparya (Sharma, 1991, p. 204; Swami, n. d). The following section discusses the scientific practices of Samkhya.

\section{Scientific Practices of Samkhya}

Samkhya is another school of thought of eastern philosophy. It is considered the oldest philosophical system of the Indian continent because the Upanishads have also found the Samkhya concept (Radhakrishnan 1952 I; Sharma, 1991). Samkhya means the right knowledge and right number, and dominantly intellectual and theoretical, where Yoga helps in practical implications of theoretical metaphysical teaching of Samkhya, so-called combined form Samkhay- Yoga philosophy (Sankar, 2011, p. 11).

The Samkhya philosophy considered as the supreme root cause of the world is called Prakriti (Sharma, 1991). Prakrti means extraordinary ability. It is the wonderful nature out of which the vast material world in all of its levels of complex variation takes shape (Radhakrishnan, 1956 II). Prakrti is considered by the three power or Gunas of Sattva, Rajas, and Tamas - the characteristic effect of the Prakriti (Sharma, 1991). It contains the nature of equilibrium (samyavastha) form in the state of rest recognised as the natural condition of Prakriti (tamas is preponderant than other two) (Radhakrishnan, 1956 II, p. 266), when there is a disturbance (vikrti), the equilibrium state (rajas is preponderant than other two) of three Gunas. We have the destruction of quiescent Prakriti, as Prakriti evolved under the influence of Purusha until all the selves are freed (Radhakrishnan, 1956 II).

Another co-present and co-eternal reality of Samkhya is Purusa, the principle of pure consciousness. It is called the soul, the self, the spirit, the subject, the Knower as a form of energy (Sharma, 1991, p. 155). About the evolutionary supremacy of Purusha, Radhakrishnan (1956 II) mentioned that "the unmanifested (avyakta) stand at the top of the 
evolution series on the plane of the matter, from which self (Mahan-atman), intellect, mind, object, and senses are spring in succession" ( $p$. 250). He further argues that Prakriti works under the control of Purushas. Mahat, Ahamkara, and Manas are the cosmic function of the supreme spirit (Radhakrishnan, 1956 II, p. 252). It is neither cause nor effect; it is unfailing light that does not change, present dreamless sleep, and instates of walking and dreaming, it is a light through which we see that there is such a thing as Prakriti (Radhakrishnan, 1956 II, p. 281).

Muller (1919) further defined Purusha as "is without beginning, it is subtle, omnipresent, perceptive, without qualities, eternal seer, experiencer, not an agent, knower of the object, spotless, and not producing" (p. 253). It follows the same experimental validation process, which follows the Nyaya and Vaisesika philosophy except for the comparison (Swami, 2009). We discuss about Yoga and its scientific practices in the following section.

\section{Yoga and its Way of Scientific Practices}

The Yoga system provides a methodological practice of linking up individual consciousness with the Supreme Consciousness. Yoga philosophy is considered complementary to Samkhya (Radhakrishnan, 1956 II; Sankar, 2011). So Muller (1919) called it Sankhya- Yoga philosophy, which is clearly mentioned in Bhagabhat Gita.5 that both are one (Swami Prabhupadh, 1997).

The methodological practices of Yoga philosophy are its practical way of attaining ultimate knowledge through the process from Yama to Samadhi (Swami, 2009). The procedural way of achieving knowledge is described below.

The first limb of Yoga is restraint (Yama), in which non-hurting, non-lying, non-stealing, sensory control, non-possessiveness, intoxication, and code of conduct are included (Sharma, 1991). Second is observation (Niyama), in which purity, contentment, austerity, study, and surrender are included (Radhakrishnan, 1956 II; Sharma, 1991). The third limb is posture (Asana) which provides for physical health and mental harmony. It tried to connect yamas and niyama with other limbs of Yoga for concentration. The meditative posture enables one to sit comfortably infirm, pleasant and easy, and steadily for a long time with the head, neck and trunk aligned adequately so that breathing may be regulated (Radhakrishnan, 1956 II), and withdraw the mind from senses; mind might be concentrated towards samadhi (Swami, n. d, p. 52). Posture is of two types: physical posture and meditation posture. There are found eighty-four physical postures helpful in meditation, but Patanjali prescribed only four physical postures for mediation practice. They are sukhasana, svastikasana, padmasana, and siddhasana. All meditation postures emphasise keeping the head, neck, and trunk straight to minimise oxygen consumption.

Fourth is breathe control (pranayama) which includes Hatha Yoga, control of vital force, awareness of the deeper level of personalityprana (breathe), establishes the link between body and mind, and vitalises both. Breathe manifestation of the vital function that strengthens the nervous system and functionalises all the mental activities (Sharma, 1991). Prana supplies subtle air and supplies the energy in the subtle body, which links the body and control of the universe, which travels from individual to the cosmos and from the cosmos to the individual. Based on organ function, prana is divided into ten types of subtle airs. In the present scenario, contemporary pathologists also considered motivating Pranayama to develop the lung's immune capacity and help to control the attack of viruses like COVID-19.

The fifth limb of Yoga is the sense of withdrawal (Pratyahara), signalling control over our senses. In other words, Pratyahara is the withdrawal of the senses from their objects and their establishment in the mind (Swami, 2009). In this Yoga, senses work as the vehicles of mind as it travels on its journey, but the mind is the master of the sense because it withdraws it. The senses by itself cannot contact or experience any objects; senses when disconnected from their objects, dwell in or dissolve into the mind (Swami, n. d, 55). It is saying that when the queen bee (mind) flies, all the bees (senses) fly, 
and when she sits, all the bees sit around her (Swami, n. d).

The sixth limb of Yoga is the Dharana (concentration), which withdraws the senses and mind from the external objects, and the mind moves towards the desired direction. External factors are not considered in this state, and the mind is concentrated in one single thought pattern through the internal process (yogic concentration). Using a mantra or the breath of the object concentration is considered the best method of pointing the mind in the mediation state. The seventh step of Yoga practice is Dhyana (meditation), considered advanced state concentration in which a single object of concentration flows without interruption (Swami, n. d). Swami (n. d) further argues that in this state, the mind becomes fully one-pointed, and by one-pointedness, the yogi can approach the super soul. And the process of "withdrawal of the senses, concentration, and meditation can be compared to a river that originates when many small streams gather and merge into one large flow of water and reach its final destination and merge in the sea" (Swami, n. d, p. 57). In comparison to meditation, wherein the initial state, the senses, and mind are withdrawn and made one-pointed, then onepointed mind flow constantly towards one object without being distracted, then it follows meditative state and siddhi (supernatural power) is expected (Swami, n. d). It helps ultimately to enter Samadhi connecting with the consciousness of the Supreme Soul.

The last state of Yoga is Samadhi (spirituality, absorption), a related word Samahitam, which means the state of one's true nature. Mind solves basic questions, flits from one mind to another, and becomes a restless ecstatic condition, and its connection with the outer world is detached (Radhakrishnan, 1956 II; Sharma, 1991). It is further argued that Samadhi is a state beyond thinking and feeling in which the individual soul is linked with the Supreme Soul and priori intuition of the truth (Swami, n. d). Thus, Yogi knows Samadhi as a mystical fulfilment of individuality, yogi reaches the highest state of peace and happiness, the individual consciousness is completely united with the Supreme Soul, become a pure devotee of God, gains entry into the eternal spiritual realism (Radhakrishnan, 1956 II), (Vaikuntha) attain knowledge of Purusha. In the next section, we discuss Poorva Mimamsa.

\section{Practices of Poorva Mimamsa as Empirical Science}

Poorva Mimamsa is considered Karma Mimamsa and Dharma Mimamsa because it investigates the nature of Dharma propounded in the former section of Vedas- Karmakanda. It is called the Poorva Mimamsa because it embraces the earlier portion of Veda, that is, the mantra and the Brahmana portion, while the latter part, that is, the Upanishads, is called Jnanakanda or Vedanta or Uttar Mimamsa, because the former deal the actions, with rituals and the sacrifice, the later study the reality (Radhakrishnan, 1956 II; Sharma, 1991). Karma refers to any action that results in a reaction, whether good or bad, whereas Mimamas mean to analyse and understand thoroughly, and considered as the stepping stone of Vedanta (Swami, n. d, p. 59). It is a technique of teaching Veda through Karma Kanda rituals, whereas Vedanta uses the same techniques in the transcendental of knowledge.

The Vedic injunctions explain the potency of sacrifices to produce heaven or some other fruits; it considered that soul as an eternal being is distinct from bodies, heaven is enjoyed by the sacrificer either in his lifetime or after his death (Radhakrishnan, 1952 I, p. 264). Swami (n. d) argues that Karma- Mimamsa considers the soul as an eternal and infinite substance with consciousness (p. 66). But soul is regarded as both conscious and unconscious (Radhakrishnan, 1952 I). About God, there is found some confusion. Jaimini, the founder of Poorva Mimamsa is found silent about the existence of God as he is about the individual soul, however, Veda is the creation of God, Brahman in the form of speech is established by one supreme spirit (atman) (Radhakrishnan, 1956 II, p. 267).

Sacrifice is made invoking for deities by obligation through the fire, believing in the 
plurality of Gods possessing in supernatural powers (Radhakrishnan, 1956 II). It does not believe liberation to be free from sin and misery, believing that a liberated soul is free from pleasure and pain and appears in proper form, becoming free from their action and leading to liberation (Radhakrishnan, 1952 I). Cosmic power is utilised by appropriate execution from ritual, then attain and expands one's potential and unite it with cosmic force, that cosmic force constantly supply[ies] light and life to all sentient beings (Swami, n. d, p. 64). So that cosmic energy, the vibration of mantra in particular shape or form called deities as cosmic energy are considered the content of present science, which is obtained through (epistemology) sacrifice in Yajna. Pratyaksa/Perception, Anuman/Inference, Upamana/Comparison, Sabda (word) or testimony are considered the main Prataksa and paroksa pramanas for achieving and transforming ways of valid knowledge in Poorva Mimamsa (Swami, 2009)

The knowledge can assess observing sacrificial function, experience sharing, behaviour change and self-reflection of practitioners. Long and Sarao (2017) suggested obtaining the moksha from the karma and about their linkage. They have suggested five categories that explain the interaction between the jiva (soul) and ajiva (non-soul) are: "influx of karmic matter into the asrava (soul), the bondage of soul to bandha (matter), stoppage of the influx of karmic matter to the samvara (soul), removal of bonded karmic matter from the nirjara (soul), and mokșa (purification or liberation)" (p. 28). Bondage means the unification of the soul with matter, and consequently, liberation implies the separation of matter from the soul (Sharma, $1991,65)$. But Chakravarti $(1952,1)$ argues that if a person knows the true nature of things, then $\mathrm{s} /$ he realises her/his pure self is the ultimate goal of life or salvation (p. 147). Uttara Mimamsa is discussed in the next section.

\section{Uttara Mimamsa/Cosmic Brahman}

Uttar Mimamsa is called as Vedanta sutra. Upanishad is considered as Vedanta, the conclusion of Veda, the essence of Vedic philosophy, Brahma-Mimamsa, deliberation of
Brahman (called Brahma-sutra), the final form of Veda, the Saririka sutra, the Absolute truth (Mulller, 1919, p. 116; Radhakrishnan, 1956 II, p. 430; Sankar, 2011, P. 47; Swami, n. d, p. 66). So it does the whole systematic investigation of the contents of the entire Veda.

Tarka or reflection is no possibility to provide metaphysical knowledge, Sruti and Smriti can be considered as the authentic source of knowledge (Radhakrishnan, 1956 II), which is called Pramana and included perception, inference, and sabda for acquiring (methods) the knowledge (Muller, 1919, p. 144).

One can say that Uttar Mimamsa can be considered as the science of cosmic Brahman, so that the practical utilisation of Jnanakanda, the theory of Brahman, nature of Brahma and its relation with world and soul can be understood explicitly. Thus, God created the universe, Brahman as a source of Prakriti and Purusha; matter and jiva are parts of Brahman, through which knowledge is obtained through (epistemology) meditation, perception, inference, and testimony of Vedic mantra. In the following section, we discuss Buddhist Philosophy and the scientific ways of practice.

\section{Buddhist Philosophy and its Scientific Ways of Practice}

Buddhist philosophy is considered a heterodox philosophy because of the nature of the scientific practice of social reality. Siddhartha Gautama was the founder of Buddha philosophy. Sharma (1962) argues that Buddha is primarily an ethical teacher and social reformer than a theoretical philosopher (p. 58). He finds out the misery of old age, sickness, and death and finds out eight truths as a practical way of doing meditation. This philosophy has seen many common arguments and is called materialistic philosophy. First, life is duhkha (means misery and pain), second, there is duhkha samudaya (the cause of suffering), third, dhukha nirodha (cessation of suffering) and fourth, the way leading to this duhkha-nirodha-gamini pratipat (cessation of suffering). Four noble truths, causes of suffering and cease the suffering can be considered the present curricular content of science teaching from basic level to secondary 
level and experimental practice and meditation that help to find and cease the suffering is considered the epistemology of teaching ways finding knowledge. We thought that it is a cause and effect relationship; that is, the cause of suffering is the cause, and cessation of suffering is an effect. It means we should search the experimental verification of the cause of suffering and cease of the suffering in practical life. There are so many ways of practising scientific knowledge, which is described below.

First, Madhyama Pratipada is an intermediate path of sat (Existence of para brahman as absolute reality) and asat (Non- existence), the middle way that enlightens the eyes and the mind, leading to rest, knowledge, enlightenment, and nirvana (Moksha/Liberation from the cycle of birth, life and death) (Sankar, 2011, Varma 1973). It avoids both eternalism and nihilism and finds a middle way between them. Second, Pratityasamutpada, or dependent originator, is the foundation of all the teachings of the Buddha (Sharma, 1962). It is contained in the Second Noble Truth (cause of suffering) which gives us the cause of suffering, and in the third Noble Truth, which shows the cessation of suffering (Sharma, 1962, p. 60). The theory of universal causation (theory of causation means the cause of suffering), Madhyama Pratipada, which the Buddha called Pratityasamutpada, is the essence of Buddha teaching or dharma or law (Chattopadhyaya, 1993). The suffering of samsarga ceases of suffering is nirvana, where both are the same reality (Sankar, 2011, p. 70; Sharma, 1991, p. 72). It looks at the samsarga, and its reality with nirvana is observed as relative; here absolute is for only binding (Sharma, 1991). It believes everything is relative, conditional, dependent, subject to birth and death and therefore impermanent, depending on causes, the effect arises; thus every object of thought is necessarily relative (Sharma, 1962, p. 61), and because of the relative, it is neither absolutely real (death) or absolutely unreal, it is said Vedantic Advaita or Maya, Buddha's middle path, Madhyama Pratipat, which avoids eternalism and nihilism, Buddha called it Bodhi, the enlightenment, identified with the Dharma, the Law (Sharma,
1962). So Chattopadhyaya (1993) argues Pratityasamutpada excludes all the theories of absolutism, nihilism, change, irregular causation and indeterminism (p. 506)

It concludes that Pratityasamutpada leads to the cessation of plurality and bliss (Sharma, 1962). There are twelve cycles of birth and death called twelve links of the causal wheel of dependent origination (Sharma, 1962; Varma, 1973) - the circle of causation, called Bhava chakra, Samsara chakra, Janma-Marana chakra, Dharma chakra, or Pratityasamutpada chakra (Sankar, 2011, Sharma, 1991, p. 74). These are destroyed if the root cause of suffering, the ignorance, is destroyed (Sharma, 1962). Moreover, it says that ignorance can be destroyed only by knowledge. Knowledge is a means of liberation; therefore, ignorance is bondage, and knowledge is liberation (Sharma, 1991, p. 74). Here one event is cause for another event, such as birth and death is causative, everything is momentary (being short time due to causal effect), ultimately unreal, so it is called relativism (Sankar, 2011; Sharma, 1962).

The third is Nirvana, regarded as the central theme in Buddhist religion and philosophy, which is considered as the state of highest happiness, rapturous, and ecstatic state of nirvanic bliss (Varma, 1973). According to Buddha, the cause of suffering, pain, and misery is burned; these are sense experiences due to sense-object contact as a result of six sense organs - these are the cause of psychophysical organism, which is the cause of consciousness of embryo, this is the cause of predisposition or impression of Karma, which is the cause of ignorance; hence ignorance is the main cause of all suffering (Sankar, 2011, p. 72). Nirvana implies eliminating pain and sorrow and getting the highest happiness and bliss (Varma, 1973, p. 243). Varma further argues that the perception of the voidness of empiric phenomena is the precondition of attaining the highest status of deliverance (p. 252) are the epistemological way of obtaining knowledge. Hence, perfect wisdom, goodness, and complete equanimity relief from pain and suffering help attain Nirvana. 
Fourth is Ksanabhangavada, whatever has a beginning has also an end, which says know that whatever exists arises from causes and conditions and in every respect impermanent, where birth is, there will come death also (Sankar, 2011). It applies to mind and matter alike for both the momentary, called sangatavada or theory of aggregation of momentary atoms, denies the eternal substance, spiritual as well as materials, is called Pudgala-nairatmya. (Sharma, 1991, p. 77). It is considered momentary; nothing is permanent, body, sensation, perception, disposition, consciousness-all these are impermanent and sorrowful (Sharma, 1962). It considers that soul is a bundle of five Skandhas - rupa or matter, Vedana or feeling, Samjna or perception, Samskara or disposition, and Vijnana or consciousness (Sharma, 1991, p. 79).

According to Sharma (1991), the first Skandha is a material or physical organism with which the other four physical Skandhas are invariably associated in empirical life, that is, the soul or the psycho-physical organism is aggregated of these five factors, as a consciousness, is real, the mind, soul or ego is unreal, the soul is an aggregated of the body, the sensation, and idea.

The fifth is Anatmavada, it considered that the law of change is the universe; either man or other living being, animate or inanimate are changeable, abiding soul (mind and body) in everybody is changeable, destroyable, and there is no salvation and eternal of soul (Bhusal, 2068 BS). Finally, it focuses on psychology without a soul (Varma, 1973).

\section{Conclusion}

This study has highlighted the epistemological understanding of finding the science embedded within eastern philosophy called Shad darsana and Buddhist Philosophy. These philosophies have provided the holistic examination of valid knowledge of Shad darsana considering the orthodox/astika philosophy and accept the authority of Vedas. Shad darsana called six philosophies of eastern knowledge: Nyaya, Vaisesika, Sankey, Yoga, Poorva Mimamsa and Uttar Mimamsa. These are found to have been developed in the post-Buddhist period (Pratt,
1933-34). There are not the same ways of validation of knowledge; however, Pratyaksa/Perception, Anuman/Inference, Upamana/Comparison, Sabda (word) or testimony are considered the pramanas for achieving and transforming ways of valid knowledge in almost all of the Shad darsana as like what we call the modern science.

The Astanga yoga system introduced by Patanjali is considered a pioneer scientific practice in the modern era for connecting mind, body, and soul with physical fitness (Swami, 2009). Hatha Yoga is mainly based on the Yoga philosophy of Patanjali, which is practised by Yogis (Pratt, 1933-34) in Nepal, and it was expanded by Yogi Guru Gorakhnath worldwide. Poorva Mimamsa and Utarmimamsa also focus on the karmic practice and cosmic Brahman as a form of cosmic energy. Buddhist philosophy is also the eastern philosophy but considered the heterodox/nastic or materialist philosophy, that is, it does not believe in the authenticity of the Veda. Madhyama Pratipada, Pratityasamutpada, Nirvana, Ksanabhangavada and Anatmavada are the scientific process that sees the world as a materialistic way so that it can claim that the scientific process is followed within Shad darsana and Buddhist philosophy.

\section{References}

Bhusal, B. (2068 BS). Nepalma prachalita darsanik chintanharu. Nepal Pragya Pratisthan.

Chakravarti, A. (1952 I). The Jain Philosophy. In S. Radhakrishnan (eds), History of philosophy eastern and western (pp. 139-151). George Allen and Unwin LTD.

Chattopadhyaya, D. (1993). What is living and what is dead in Indian philosophy (3rd ed.). People's Publishing House.

Gupta, B. (1980). Are "hetvabhasas" formal fallacies. Journal of Indian Philosophy, 8(2), 135147. https://www.jstor.org/stable/23440725

Long, J. D. \& Sarao, K. T. S. (Ed) (2017). Buddhism and Jainism: Encyclopedia of Indian Religions. Springer.

Muller, F. M. (1919). The Six Systems of Indian Philosophy. Longmans Green and Co. 
Pratt, S. (1933-34). The system of Hindu philosophy. East-West Magazine. http://devotee2devotee.com/wordpress/wpcontent/uploads/2018/02/Tara-Mata-TheSystems-of-Hindu-Philosophy.pdf

Radhakrishnan, S. (1956 I \& II). Indian philosophy (8th ed.). MacMillan.

Radhakrishnan, S. (1952 I). History of philosophy eastern and western. George Allen and Unwin LTD.

Sankar, L. (2011). Introduction to Indian philosophy. University of Calicut.

Sharma, C. (1962). Indian philosophy: A critical survey. Barnes and Noble, INC.

Sharma, C. (1991). A critical survey of Indian philosophy (8 th ed). Motilal Banarsidass.

Swami Pravupadh, A. V. (1997). Bhagavat Gita as it is (Trans). Bhakti Vedanta Book Trust.

Swami, H. (2009). The Six Systems of Hindu Philosophy: A primer. Sri Ramakrishna Math Pres.

https://estudantedavedanta.net/The_Six_Syste ms_Hindu_Philosophy_Harshananda.pdf

Swami, S. (n. d). The Six Systems of Vedic Philosophy.
https://www.academia.edu/2127380/THE_6_S

YSTEMS_OF_VEDIC_PHILOSOPHY

Varma, V. P (1973). Early Buddhism and its

Origins. Munshiram Manoharlal Publishers Pvt. Ltd.

\section{Conflict of Interest}

There are no conflicts of interest concerning the research, authorship, and publication of this study.

\section{Acknowledgements}

The authors would like to acknowledge all the anonymous peer reviewers who provided quality input and suggestions for improving and finalising this manuscript.

\section{Author Contribution Statement}

Kamal Prasad Koirala (corresponding author) contributed to searching the literature, conceptualisation and designing the manuscript; writing the first draft; reviewing and re-writing the final draft.

Professor Bidya Nath Koirala contributed in reviewing the initial manuscript and supported in the final preparation of the draft.

Dr Gem Prasad Gurung supported the generation and conceptualisation of the initial draft of the manuscript. 